ÉGYPTE monde arabe

\section{Égypte/Monde arabe}

4 | 2007

Figures de la santé en Égypte

\title{
Madman Walking. The image of the mad in the Egyptian press
}

\section{Ahmad Ragab}

\section{(2) OpenEdition \\ 1 Journals}

\section{Electronic version}

URL: https://journals.openedition.org/ema/1773

DOI: $10.4000 /$ ema. 1773

ISSN: 2090-7273

\section{Publisher}

CEDEJ - Centre d'études et de documentation économiques juridiques et sociales

\section{Printed version}

Date of publication: 31 December 2007

Number of pages: $227-246$

ISBN: 2-6905838-43-4

ISSN: 1110-5097

\section{Electronic reference}

Ahmad Ragab, "Madman Walking. The image of the mad in the Egyptian press", Égypte/Monde arabe [Online], 4 | 2007, Online since 31 December 2008, connection on 07 July 2022. URL: http:// journals.openedition.org/ema/1773; DOl: https://doi.org/10.4000/ema.1773 


\title{
Ahmed Ragab
}

\section{MADMAN WALKING ${ }^{1}$}

\author{
THE IMAGE OF THE MAD IN THE PRESS
}

\begin{abstract}
"In an unprecedented incident in Al-Hussein Mosque, during the Friday prayer, a young prayer mounted the minbar with a small knife in his hand and urged the Imam to address, in his speech, the concerns of the people... The young man said that his mother is gravely ill and is being treated in Al-Demerdâsh hospital, where she suffers from serious neglect. The police was able to arrest the young man... The investigations revealed that the accused... suffered from psychiatric illness and was currently unemployed"
\end{abstract}

Al-Ahrâm, Saturday, 2 December 2006

$\mathrm{T}$ his article questions how the Egyptian press, during the last decade, drew the image of the mad criminal. The article examines Egyptian newspapers representing the three main pillars of today's Egyptian press, namely stateowned (Al-Ahrâm, Al-Akhbâr, Al-Jumuhûriyya, Rûz al-Yûsif, etc.), independent (Al-Maydân, Al-Usbû', Sawt al-Umma, etc.) and opposition newspapers (AlWafd, Al-Ahalî, etc.) during the period starting from the mid-1990s up to today. The article will try to follow the build-up of the "journalistic story/discourse". It will start from the point where the proof of madness is established. Then it will approach the construction of the discourse, both linguistic and pictorial, concerning the mad; the results of such discourse in the form of demands of actions taken towards the mad criminals and the mad in general; and finally,

1. In reference to Helen Prejean, Dead Man Walking, Vintage: Vintage Editions, 1994. In 1995, Tim Robbins transformed the book into a movie of the same name, starring Sean Penn and Susan Sarandon. It tells the story of Sister Helen Prejean who comforted a convicted killer on death row. It was considered one of the most antideath penalty movies ever made. 
the exceptions and excuses of madness, which provide a better understanding of the mechanisms of formulation of the discourse.

\section{On the mad...}

The mad invoke the fears of the unknown and the anxiety of the bizarre. His/ her disease is incomprehensible and inexplicable. His/her failure to understand reality or his/her unconformity with the values and expectations of society, his/her stray looks, strange mutterings and "extraordinary" strength have put him/her on the margins of society.

The mad criminal is an important psychological and sociological phenomenon. At the psychological level, "Les figures du fou et du criminel sont intimement liées à notre conception du lien social.» ${ }^{2}$ The failure of both the criminal and the mad to conform to the expectations of society and to meet and fulfil its rules brings them closer together in the collective consciousness. This could explain the remarkable success of movies from «Psycho» up to «Seven» and other movies, which depend on the special link between the mad and the criminal or the presentation of the mad crime. ${ }^{3}$

'Mad' and 'madness' are notions, which justify a certain degree of alienation and estrangement. His/her inability to meet the requirements of living with others in the social space represents a pretext for exclusion and alienation. The crime committed by the mad is a danger to the society posed by those who fail to join it and/or refuse to comply with its rules. This danger, thus, elicits more exaggerated responses than those resulting from the "ordinary crime." The social response to the "crimes of the mad" being augmented by the alienation of the mad, reveals more of the protective mechanisms used by society to protect itself and protect its own image.

\section{On "Hawâdith" or Accidents}

Apart from the political critique or news reporting and the gossip-oriented society and sports sections, the "Hawâdith"4 (accidents) is a ubiquitous section in all Egyptian newspapers. And though this section is usually of high popularity among readers, the state-owned TV and Radio, which have a much wider

2. "The representations of the mad and the criminal are closely linked to our conception of social ties." (Renneville, 2003, p. 15).

3. Ibid.

4. In the Egyptian press, the word "accidents" is used to describe the section of crimes, trials and accidents. In this paper, "accidents" will be used to refer to that section. 
public in the half-illiterate Egyptian society, have slight, if any, presentation of such types of news, apart from scattered news about politically-related crimes and one or two weekly shows celebrating police exploits. ${ }^{5}$ Although not very widely spread, newspapers remain dominant in the field of "Accidents".

Being one of the most popular state-owned newspapers in Egypt, Al-Akhbâr made one of the first trials to issue a paper specialized in "Accidents". The slogan was coined shortly after and was reproduced on TV channels, "The Aim: Crime never does any good and punishment is always certain."

Crime has always been pictured as moral deviation and violence has been seen as alien to the happy society. The social role of the press is to pursue such deviation, assure its worthlessness and see it to a just punishment; such pursuit was always based on a "thick" moral basis. ${ }^{6}$ An example of such treatment is the incident of Raiyyâ and Sakîna, accomplices of multiple murders of women for the purpose of robbery in Alexandria, which was the beginning of a wave of articles portraying different features of "social morality". In fact, the method of coverage in the Egyptian press signalled the emergence of a mass culture in 1920s Egypt coinciding with the emergence of nationalism. Moreover, the press coverage of the incidents and the reviews written about them were used to assist the birth of a common national "morality" and the image of the Egyptian society (Lopez, 2005).

Except for some politically oriented issues, the police and the judiciary are not to be questioned inside the "Accidents" section. Their wits and their care for the society are esteemed to be beyond doubt. The relationship of the reporter and the police officer, who is the major if not the only source, is a priority. Accordingly, the press should refrain from any critique or demands of disclosure. The fight against crime is the priority.

An important remark while reading "Accidents" is the overwhelming similarity among reports from state-owned, independent and opposition papers. The reports come from the same sources, usually police officials, who inform almost equally all reporters. The relationship between the "source" and the reporter is thus crucial. Any critique or suspicion should be kept to a minimum and neither the police nor the judiciary should be overtly criticized by reporters, except in very rare situations where the politicization of the report is inevitable.

5. An example is the program "Warâ' al aswâr", which is shown during prime viewing periods on the TV's first channel and discusses the success of police in bringing down criminals.

6. For more details: see also Walzer, 1994. Walzer differentiates between two languages of morality: a thick morality, stuffed with principles and values and visions of the world, and a thin morality, focusing on the general, shared values. Borrowing Walzer's conceptualization, the article describes the moral basis as thick, being full of rhetoric about right and wrong and other visions of society. 


\section{Reading the Egyptian press}

In his analysis of the press, Pierre Bourdieu considers it as one of the spaces of competition among different social actors for symbolic power (Bourdieu, 1991). In their struggle, they aim at coining certain metaphors, which would compose a "public opinion", ensuring more and more "social capital". A study of media or journalism, assuming this given, should not be different from studying any literary or artistic field and should concentrate, not only on the discourses and presentations used by this medium, but more importantly, on the roles played by different social actors and their struggle for symbolic power and capital.

Applying such a methodology to Egyptian society and the Egyptian press is very challenging. A long-established, authoritarian, corrupt regime, which has monopolized for decades and continues to monopolize the public spheres, has done its best to render different social actors more and more domesticated and incorporated within the framework of a single voice. These trials of the regime, oscillating from ultimate success to relative failure according to time and circumstances, have modified the social landscape quite different from the traditional Bourdieusian struggle to images of negotiations, containment, incorporation and even identification; and from multiple voices to a swinging between an echoless single voice and a voice with multiple, sometimes distorted echoes. A sociological analysis of such a landscape has to take into consideration all possible representations of the different social powers, their networks of relations and their connections, among other things. An important addition to sociology, in this case, is the discourse analysis. This approach should allow for more permeability of the research medium through permeating/analyzing its more obvious and overt representations/discourses and benefiting from such an understanding to "portray" the social landscape with all its complications, relations and interconnections.

Thus, the article has opted for a methodology based on discourse analysis in an attempt to trace the journalistic discourse of madness as revealing of different social powers with their complex network of relations.

\section{ESTABLISHING PROOF OF MADNESS}

The Egyptian criminal law recognizes the court as the supreme expert in all fields. The judge has the authority to call for the advice of certain specialists in certain issues and has the right to dismiss their advice and act not in accordance with it.

Declaring mental illness in the court of law is thus the responsibility of the judge, who usually refers the "accused" ${ }^{7}$ to a mental hospital or to a specialist of psychiatry to give a professional opinion about his/her "mental capacities". The legal declaration of madness is thus a lengthy process, which requires a number of procedures. The journalistic declaration of madness, and the 
journalistic proofs that are given to the readers, are based on a much faster decision and are issued in different reports without awaiting the judgment of the judiciary. In this part, the legal proof of madness is not the main concern but rather the journalistic proof of madness.

On March 18, 2004, Ayman Al-Sebâ'î writes in state-owned Al-Jumuhûriyya under the title: "The noon crime that shocked Al-Nozha: three victims and the killer is Mad." The crime took place in Al-Nozha neighbourhood in Cairo, where the accused slaughtered a neighbour and his daughter, as well as another neighbour who happened to pass by.

Under the first subtitle "The Start", the article tells the story of the accused who "suffered from psychological disturbance after his father's death... The mother of the accused would take him to several psychiatric hospitals for treatment... that he still visits to obtain treatment." ${ }^{8}$

In this case, the nature of the alleged psychological disturbance was not mentioned. Instead, the journalist stressed the fact that the accused consulted a psychiatrist and visited psychiatric hospitals. The relation with the "field of psychiatry", in the form of physicians, hospitals and/or treatment, was the determining factor in proposing an accusation of madness.

In December 2005, following the murder of ten people in Bânî Mazâr in al-Minyâ governorate and the mutilation of their sexual organs and fingers, the police accused a young man of committing the crime. Al-Wafd, the official newspaper of Al-Wafd party, said "Security forces pursued their efforts to uncover the mystery of the crime... and are still questioning the mentally disturbed [man] who was arrested as the first suspect in this brutal crime. It was known that he visits a psychiatrist. And the police obtained a report from the psychiatrist, who assured that the patient suffers from multiple personality disorder and is liable to commit extreme violence." ${ }^{\prime 9}$

Rûz al-Yûsif quotes the medical reports, "the accused has been under treatment since 2003 from multiple personality disorder, mania and Obsessive Compulsive Disorder and could commit any action without being aware of it, and has great hostility towards his neighbours and also, he stopped taking his medicines 15 days before the incident."10

7. Unlike the Anglo-Saxon legal literature, in the Egyptian literature, the defendant is called the accused. This article will follow the latter nomenclature.

8. Ayman Al-Sebâ'î, "Three victims and the killer is mad", Al-Jumuhûriyya, March 18, 2004.

9. Mamdûh Hassan and Khâled Idrîs, "The security continues its efforts to uncover the mystery of the massacre of Shams al-Dîn Village in al-Minyâ", Al-Wafd, January $1,2006$.

10. Sayyyed Ghânem, Mahmûd Deyâb, Zakariyyâ Ahmad and Shaima' Abû-I-Layl, "The accused: a calling from the sky ordered me to do the massacre", Rûz al-yûsif, January 4, 2006. 
The accusations of the police were not subjected to any form of investigation. They were taken for granted, even by an opposition paper. Again, the proof of madness was his visits to psychiatrists and a medical report, which contained a number of inexplicable and irrelevant notions. The presence of such notions indicates that neither their meaning nor the contents of the report were important. Only its mere availability was.

In April 2006, three different churches were attacked in Alexandria, the police accused Mahmûd Salâh al-Dîn 'Abd al-Râziq, a worker, of performing the assaults. The attacker "suffers from psychological disturbance... and he received treatment and psychological sessions in Al-Ma'mûra psychiatric hospital."11 Again, the visits of the accused to the mental hospital, his receiving psychiatric medications and/or visiting a psychiatrist were all sufficient proofs of his madness. The reporters used sometimes multiple mixed names of diseases and disorders, which remain far from the perception of the layman. The message to be delivered is that "he" has a problem in his mind.

In the examples, the medical history of psychiatric consultation was a crucial factor in proving madness in the press. In doing so, the reporters and journalists relied on the authority derived from the medical expertise and the medical terminology, which were part of the reports in multiple cases. However, the medical authority was not the only stone used to build the proof of madness.

In the case of the Al-Nozha killer, the reporter adds that he had left his job as a government employee twenty years before. ${ }^{12}$ Another article about the same incident starts with a surprise: "the surprise is briefly that the madman of Al-Nozha is not mad."13 The hospital, where his mother said he was being treated, denied any relation with him. The reporter, though presenting the surprise at the beginning of his article, brings about all "pieces of evidence" of his madness. He refuses to pray in the mosque because no one is good enough to be his imam, he left the government job because the money of the government comes from prostitution and drugs. "Strangely, his neighbours said he is a polite person and apologizes if he makes a mistake."14 Here, the reporter brings about the different acts of the accused, which can be considered strange and incomprehensible. The fact that his neighbours found him polite and calm is brought about as "strange" in relation to what' expected of a madman. At the end of the article, the reporter writes the conclusion, "after his father's death,

11. Zaynab Yûsif and 'Âdil Helmî, "Mentally disturbed attacks two churches and tries to sneak to a third", Akhbâr al-yawm, April 15, 2006.

12. Ayman Al-Sebâî, op cit.

13. Îhâb Hegazy, "Muhammad al-Tûmî left the government job because the government money is dirty and killed his neighbors to get rid from their annoyance", Sawt al-umma, March 22, 2004.

14. Ibid. 
he had a psychological crisis and became an introvert and refused to deal with others. And when his mother took him to many psychiatrists, they said he had multiple personality disorder and he was fired from his job because of that, so his mother kept him at home and prevented him from going out at all."15

In the same context, Al-Sebâ î writes about the accused being "in a state of rage with sparks coming out of his eyes."16 He describes his enormous strength that prevented the neighbours from controlling him and tells that "he kept muttering incomprehensible phrases." ${ }^{17}$ Here, the traditional image of the mad or the possessed, as extremely strong with sparks coming from the eyes and rage that could destroy everything around him, is brought into play as well.

Similarly, in the assault against the churches in Alexandria, the reporters quoted the mother of the accused stating that her son beats people and then does not know what he did. More incidents about him beating up other people during his period of obligatory military service were also brought about. ${ }^{18}$ The reporters added that the accused goes into cyclic periods of "rage" that recur every April. ${ }^{19}$

In all the previous examples, the journalists depended on two key factors in issuing a judgment of madness and in provoking their readers into approving of their judgment. First, the journalists depended on the medical authority of the psychiatrists and the medical reports as irrefutable judgments of the experts. Second, they stressed the actions of the "subject" being incomprehensible and unlikely to come out of a "sane" person.

\section{THE MAD AS A THREAT}

As with any significant incident or crime, the crimes of the "mad" were usually followed by certain repercussions and echoes in the press. The articles following the event were usually aiming at and/or revealing of a certain understanding of "how things should be" and how society should react to the concerned incident and similar incidents.

On April 1, 2004, a teacher in al-Minyâ governorate was accused of murdering his three children in revenge of his wife. There was not much to say about his previous psychiatric history. He never consulted a psychiatrist and

\section{Ibid.}

16. Ayman Al-Sebâ'î, op. cit.

17. Ibid.

18. Michael 'Âdil, Mu'men Anas, Zakariyyâ Ahmad, Muhammad Zakariyyâ and Walîd Abû-I-'Ela, "Rûz Al-Yûsif" publishes the real motives behind the assault on Alexandria churches", Rûz al-yûsif daily newspaper, April 16, 2006.

19. Ibid. 
never attended a mental hospital. Bâhî al-Rûbî, though, reported the incident in Al-Jumuhûriyya under the title, "Nehâl, Khulûd and Ziyâd... victims of a mad father and a greedy mother." 20 The reporter used the details of the murder to justify the madness of the accused: the father took his children from school, killed them in his house and burned the whole apartment, then confessed to the school headmistress who did not believe him and then fled to Al-Hussein to live as a beggar until he was finally arrested. All are actions which cannot be committed except by a mad man. Three days later, Mamdûh Hasan wrote an article in Al-Wafd entitled, "So that the massacre of al-Minyâ would not recur: 7 million psychiatric patients threaten to take revenge on their families."21 The article was headed by the photo of the teacher. The journalist explains that studies, the nature of which he never explains, affirm that $30 \%$ of the inmates of mental hospitals were convicted in crimes, "which is a ratio higher than that of criminals to ordinary individuals." 22 He quotes Dr. Magdî 'Arafa, a professor of psychiatry at Al-Azhar University, saying, "The psychiatric patient is a time bomb that could explode at any moment. And the massacre of Menia could recur at any time, since there are thousands of patients living among us without treatment." 23

Similarly, after the massacre of Bânî Mazâr, Turkî and 'Abd al-'Azîz wrote in Al-Ahrâr, under the title "The Bânî Mazâr killer opens the file: Mad and Murderers. 650 thousand psychiatric patients threaten society... anyway, the case opened a sensitive file about the psychologically disturbed murderer who lives freely among us with his hands on the trigger or a sharp weapon, ready to kill any person whom his thinking drives him to get rid of." ${ }^{24}$ Turkî writes again about the same topic, in the same newspaper, after the assault on the Alexandria churches. Under the title "Crimes of Official Madness," ${ }^{25}$ he writes, "It is the bloody series of the mad living in the streets and the chronic schizophrenic patients who enter history through the gate of crime and become stars on the pages of newspapers just as they had dreamt." He quotes Dr. Hâshim Bahary, a professor of psychiatry at Al-Azhar University: "The psychological patients committing crimes is well expected, especially with the increase

20. Bâhî al-Rûbî, "Nehâl, Khulûd and Ziyâd... victims of a mad father and a greedy mother", Al-Jumuhûriyya, April 1, 2004.

21. Mamdûh Hasan, "So that the massacre of al-Minyâ would not recur: 7 million psychological patients threaten to take revenge on their families", Al-Wafd, April 4, 2004.

22. Ibid.

23. Ibid.

24. 'Alî Turkî and Mamdûh 'Abd al-'Azîm, "The killer of Bânî-Mazâr opened the file: Mad and Murderers, 650 thousand psychological patients threaten the society", AlAhrâr, January 8, 2006.

25. 'Alî Turkî, "Crimes of Official Madness", Al-Ahrâr, April 21, 2006. 
in their numbers in public places and bus stops." ${ }^{26}$ And he insists that the psychiatric patient commits any violent act for fame and to draw attention, explaining that the psychiatric patient is sometimes an envious person, who resents society and enjoys hurting others.

In the previous examples, the crime of a person, who was said to be mad, was a trigger to reports and reviews discussing the situation of mad people in the streets. The only critique to the mental hospitals and the ministry of health was not directed to the treatment of the patients, but to the absence of enough beds inside the hospitals to host all the "4 million patients" in the streets. ${ }^{27}$

The mad were classified as a threat to the society ${ }^{28}$ and this threat was linked to their potential tendency to violence and to revenge against society. ${ }^{29}$ The clear diagnosis of their diseases and the differentiation between different types of psychiatric, mental and/or psychological illness did not seem to matter. Experts and doctors were quoted only to indicate the great danger of these patients, not to explain any details about their conditions. In all cases, the reader was always supposed to be someone who never experienced such problems, who is not one of the alienated "4 millions" or even their relatives or friends. The mad, incorporating all types and varieties of psychological and psychiatric illness, are a threat which has to be dealt with.

\section{STRETCHING THE DISCOURSE: MADNESS AND DISTURBANCE}

From the previous examples, it appears very difficult to give a clear definition to the word "madness". Madness is obviously being used to describe all sorts of psychological and mental disturbances and symbols of social disorder. Madness, though, is not only a word. It is more like a notion that encompasses different criteria and incorporates a perception of reality or the reality of some people, seen as different/deviant. Madness is indeed a discourse, which has its own discursive formation and uses specific characters for inclusion and exclusion (Foucault, 1969a, 1969b). The madness discourse expresses itself most clearly in the press, where the statements used to incorporate certain objects in its discursive formation include referring to psychiatrists, "specialists" and professors of psychiatry, in the name of their professional "authority" and "experience", along with the repeated description of various "weird", "unacceptable" or "irrational" behaviour exhibited by the object/person to be called "mad". This discursive formation of madness becomes a continuous process that provides a tool for incorporating more objects within the realm

26. Ibid.

27. Ibid.

28. 'Alî Turkî and Mamdûh 'Abd al-'Azîm, op. cit.

29. Mamdûh Hasan, op. cit. 
of the discourse where specific rules apply, specific judgments dominate and specific perceptions of reality prevail. Such objects do not have to be persons, but could also include behaviours or social phenomena, which are to be alienated and estranged from the "fabric" of the society.

Asma 'Ismat, in Al-Ahrâr, writes an analysis of the violent attitude in society. She quotes Dr. 'Abd al-'Azîz, a professor of psychiatry in Banhâ University, speaking of the different pressures imposed on the individual driving him/her to explosion. ${ }^{30}$ In the same article, she speaks of multiple "accidents" in which violence was "incomprehensible" or "abnormal"; a student fighting with a taxi driver over the fare and a person opening sutures on his abdomen while held in police custody. The journalist does not analyze any of the examples she mentions: the fight between the student and the driver is a normal occurrence in Cairo's daily life, the person supposedly opening his sutures could have been assaulted by inmates or even by the known-to-be-brutal police. The reporter chose to mention such incidents in the framework of "weird and incomprehensible behaviour", which is alien to the society and needs to be explained through the advice and opinions of professional experts/psychiatrists.

In Al-Wafd, Amâny Salâma writes, under the title "Killing for the slightest of reasons"... "These crimes are a reflection of psychological pressure and despair." She quotes a professor of psychiatry, she does not say where he works, and a member of a so-called "World Federation of Psychological Health" saying, "Losing hope and confidence accompanied by the loss of psychological and social stability... leads to despair and depression." ${ }^{31}$.

Dr. Al-Gebâly, a professor of "psychological education" in Cairo University, in an article under the same title of Al-Wafd's article but in Al-Jamâhîr, is quoted saying, "A great ratio of the recent crimes was committed by people who are not natural criminals, but who went through hard experiences during their childhood." 32 The anonymous reporter quotes a professor of neurology in 'Ayyn Shams University to delineate that "the most important reason behind this phenomenon is the marginalization of religion in our lives." Another professor of psychology in 'Ayyn Shams University was quoted to ascertain the responsibility of crowdedness.

In the previous article of Al-Jamâhîr, the journalist starts the article with the details of multiple, horrible, "abnormal" crimes, presented in bullet points. He uses the same statements as the previous discourse, quoting psychiatrists and psychologists, but not only to analyze the phenomenon that he is trying to describe, but also to deliver a religious message and messages about "crowdedness". The discourse of the "specialists", though devoid of any real

30. Asma 'Ismat, "Life's pressures are behind the violent behavior", Al-Ahrâr, October 2, 2004.

31. Amâny Salâma, "Killing for the slightest of reasons", Al-Wafd, January, 21, 2006.

32. "Killing for the slightest of reasons", Al-Jamâhîr, November 3, 2004. 
scientific analysis, are taken as science and are used to alienate the phenomenon of violence from society. The alienation of such phenomena is used for two purposes: preserving/recreating a certain image of the society and advocating religious messages.

In all the previous examples, the journalists used the same statements, which were used in the previous discourse, in the form of the characters and declarations of the psychiatrists and psychologists and the fact that such actions are "incomprehensible" and "weird". The same modalities, which were used to incorporate the mad criminal into the discourse, were used to incorporate other objects within the realm of the same discourse. The objects were social phenomena, such as violence, which are intended to be extracted from the fabric of the society. The incorporation of such objects in the realm of the discourse serves to preserve the image of society as immune to such phenomena and problems.

From the linguistic point of view, the intended image of society is served by distancing the crimes from the reader. The reporters write in a way which presents the crimes and the phenomena at hand as being distant and alien to the reader. In this regard, killing is described as being "for the slightest of reasons," in different articles, in different newspapers. Such description makes the crime beyond explanation by neglecting its reasons. An act, which has no reasons and no justification, is more liable to be distant and alien. Journalists tend to use the plural first person to describe the witness, "We hear a lot of citizens saying that pressure leads to explosion." ${ }^{33}$ Accordingly, the journalist and the reader are united in the plural first person who witnesses the events and the strange phenomena but who has no part in them. These methods add more to the alienation produced by the discourse. Moreover, the journalists tended to 'bio-medicalize' these phenomena in an attempt for de-politicization of the debate around such issues.

\section{THE CRIME OF THE MAD OR THE MAD CRIME?}

In mid-September 1998, Mubarak's presidential vehicle was approached in Port-Said by a citizen, who was killed on the spot by the presidential guard. Shortly after, the Egyptian TV and Radio assured the "panicking" people that their president is fine. They added that he was attacked by a madman who had a knife and injured the president's hand.

From the political point of view, the president/pharaoh has always been a taboo. The semi-divine nature of the ruler-till-he-dies remains hanging over the heads. During the campaigns of the first presidential elections, the overwhelming majority of the candidates refrained from any "inappropriate" comments on the person or the achievements of Mubarak.

33. Asmaa Esmat, op. cit. 
Except for the last one and a half years, political criticism was always directed towards the cabinet and the prime minister, keeping the president, the symbol of the state, out of the field of criticism. The political taboo includes not only the moral character of the president, the symbol of the state, but more importantly, his physical character, the embodiment of this symbol.

The case represents a clear violation of the political taboo of the president. A similar violation was very recently seen through the attempt on Mubarak's life in Addis Ababa. In the Addis Ababa case, the president's courage and temper and the bravery of his guards were celebrated by the media and their behaviour was a model of how the state faces terrorism. However, killing a man on the spot cannot be celebrated as a heroic act of the president and his brave guard. The "attacker" cannot be a terrorist as this is not the way the State handles terrorism. However, as he perpetrated such an attempt, the attacker had to be mad.

Only some weeks later, it was disclosed that the attacker had a single visit to Dr. Magdî Mustafâ, head of department of psychiatry in Al-Nasr hospital in Port-Said. The psychiatrist recalled the date of that single visit, on September 6,1995 , and claimed that the patient suffered from "mental disturbance" that could only be treated by sleeping pills!!! ${ }^{34}$

The classical proof of madness was delivered at the end. However, its confused nature allows for suspicion. What is important here is not whether that visit to the psychiatrist occurred, but the timing of the introduction of the story in the formulation of the discourse. Its being introduced much later than the claim of madness questions its role as the main statement needed to include the object within the realm of the discourse. The main proof of madness was not the visits to the psychiatrist or the mental hospital, as this story was introduced much later than the claim of madness. The main proof was, though, the nature of the crime itself; a break of a taboo which can never be made except by a madman.

A further example of breaching the political taboos concerns the relations between Muslims and Copts which remain critical to the legitimization of the ruling regime. In spite of many successive incidents and clashes and unhidden tensions, the harmony and perfect cohabitation between them is a "fact". Any violation of this fact is thus a violation of another political taboo.

With the first reporting of the attacks on some Alexandria churches, the Egyptian TV declared that the attacker was a madman. A few days later, 'Âdil Hamûda, a government-leaning journalist, was brought to a TV talk show to present his exclusive interview with the "madman" and to present the classical proofs of madness; the successive visits to psychiatrists, the weird-looking eyes, the strange mutterings...

Again, the question is whether the classical proofs played the main role or not in proving the madness of the accused. 'Abd Allâh Kamâl wrote in

34. 'Alî Turkî and Mamdûh 'Abd al-'Azîz, op. cit. 
Rûz al-Yûsif: "Some crimes cannot be committed except by a disturbed person... When someone enters a church and attacks the believers, he is certainly disturbed." 35 In fact, the course of the events lends a hand to answering the previous question. The authorities provided the "classical" evidence of madness only following the rising doubts of the public about the truth. The question though is not whether the man is the attacker or if he is mad, but how the proof of madness was first constructed. The authorities used, in the beginning, the nature of the crime to prove the madness of the criminal. Only when the gravity of the act and the pre-existing tensions posed more than necessary doubts, did the authorities resort to the classical proofs of madness to assure the inclusion of such objects, the attacker and the act, within the realm of the discourse and, thus, their total alienation.

In the massacre of Bânî Mazâr, the brutal nature of the crime shocked the moral sense of the society. The crime was labelled "brutal", "atrocious", etc., showing the grave nature of the crime and the waves of resentment it produced. The image of the safe and calm society was endangered and its perception of itself threatened.

Ghannâm and others wrote in Rûz al-Yûsif: "The investigation team came to know that one of the inhabitants of the village suffers from psychiatric illness. This piece of information, though simple, intrigued the members of the team especially with no acceptable explanation of the accident" ${ }^{\prime 36}$ In this example, as in the previous ones, the first proof that the criminal was mad was the nature of the crime itself. The horrible crime had no acceptable explanation, and thus, whoever committed it had to be mad. The role of the investigation team was then to find the closest madman to the location of the crime who would certainly be the first suspect, then the criminal.

In fact, this example offers an even graver finding. Not only was the strange nature of the crime used as a proof of madness or as a statement in a journalistic discourse, but it was also the primary reason of suspicion by the investigation team. The discourse, thus, has its inevitable repercussions in the fields of public and official action.

The overt violation of religious taboos was also treated in the same manner. Accusations of madness were fired easily against multiple cases of individuals declaring themselves prophets and messengers of God. However, these cases remain under-documented for various reasons.

In the previous examples, the classical proofs of madness were not the crucial factors in producing a judgment of madness. On the contrary, the action/crime in itself, which was a violation of a certain taboo or another, was a sufficient proof of madness.

35. 'Abd Allâh Kamâl, "A word of bad reputation", Rûz al-yûsif, April 16, 2006. 36. Sayyed Ghânem, Mahmûd Deyâb, Zakariyyâ Ahmad and Shaymâ' Abû-I-Layl, op. cit. 


\section{THE VERBAL AND THE PICTORIAL}

In all the previous examples, the verbal/linguistic component of the discourse was the main target of the analysis. However, the verbal component does not represent the whole discourse. The pictorial component includes not only the photos or the pictures shown in the articles, but also and more importantly, their size, their place, their captions, etc. The pictorial discourse includes, as well, the different typing fonts and the methods by which the titles are chosen and written.

The importance of the pictorial discourse, taken as explained above, lies in two aspects. First, the pictorial discourse is more capable of spreading. For the over-the-shoulder readers in metro and bus stations, the pictorial is much easier to follow. For the shop window readers, the pictorial is a reason for buying the paper and a very vital method to know what is inside.

Moreover, the involvement of the pictorial discourse within the process of marketing adds to the burden of the reporter and the editor. To be marketable, the pictorial discourse has to be accessible to all "spectators". This implies the use of common symbols that can be easily understood by all possible spectators. This makes the statements of the pictorial discourse more fitting to the "common sense" or, in other words, stereotypes, which could be more attractive and appealing to the spectator. The study of the pictorial discourse, then, allows for the better understanding of the method, by which the reporters and editors are addressing the common sense of the people.

The second aspect of importance in the pictorial discourse is the fact that the pictorial discourse is not debatable. Photos, for example, remain representative of the truth without needing explanation, justification or deductions. The comments under the photo are integral parts of the photo itself. The titles and subtitles, written in specific fonts and formats, are also indisputable. They are "bullets" thrown in the air and remain hanging over the heads of the readers throughout the article. Though not entirely ethical, many journalists do not feel obliged to write and choose titles which best describe the content of the article.

In the massacre of Bânî Mazâr, Ghannâm and others chose an interesting title for their reporting on the course of investigation: "The accused: A call from heavens ordered me to commit the massacre!"37 The reporters chose to add an exclamation mark at the end of the alleged quote. The title was written in the boldest font possible and it contained a striking evidence of madness: the accused claims the interference of divine forces, which ordered him to commit the massacre. On the left side of the article, the reporters showed a photo of the accused with a vacant expression. Although the photo in itself is not especially remarkable, the comment under the photo is more interesting. The reporters wrote: "The slaughterer". The expression of madness of the

37. Sayyed Ghânem, Mahmûd Deyâb, Zakariyyâ Ahmad and Shaymâ' Abû-I-Layl, op. cit. 
accused is formulated through different methods from the pictorial point of view. First, the main title contains striking evidence of madness in the form of inconsistent and incomprehensible behaviour. Second, the chosen photo shows the accused rather dull and vacant, while the comment under the photo serves to indicate the severity of the crime. The coexistence of the previous elements recreates the traditional image of the violent madman, who appears to be innocent and harmless.

In all the previous examples, the pictorial discourse took two important forms in two different forms of writings: the first type of writing is the immediate reporting of the event/accident. In this case, the aim is to coin a proof of madness against the accused. And here, the pictorial serves not to add to the chain of proofs of madness but rather to intensify its effects, either through throwing out the accusation in the heart or in the beginning of the article in very provocative titles or through presenting a photo of the accused. The titles contain words like "mentally disturbed" 38 or "mad", 39 while the photos present the accused looking strange or staring at the camera ${ }^{40}$ and/or photos showing the severity of the crime and the harm done to the victims. ${ }^{41}$ The photos of the crime serve to add more to the horror of the crime, while the photos of the accused are coined to be symbols of madness and disturbance. The second type of writings speaks about the general threat posed by the mad to the society. In such articles, the reporters use the photos of "mad" people, photos of psychiatrists and psychology experts, and photos of some of the accidents. These articles usually appear after crimes done by the mad. The photos of the criminals have been used as symbols of madness to induce memories of such crimes and thus to justify any actions demanded against "the mad". The photos of the crimes serve to intensify the feeling of danger transmitted to the public, while the photos of the psychiatrists establish the credibility of the article and "correctness" of the judgments passed through it. The titles of the articles focus on the numbers of the alleged mad and their existence in the society "among us". The aim of such articles is to transmit a feeling of fear of the mad and the problems they could cause.

\section{UNCOVERING THE PLOT: EXCUSING MADNESS}

The narrative modalities of a discourse are usually more complex than expected. The alienating discourse on the mad is not simply a speech act against the mad or a declaration of condemnation. In fact, this discourse is

38 Zaynab Yûsif and 'Âdil Helmî, op. cit.

39. Ayman Al-Sebâ'î, op. cit.

40. Ibid.

41. Ibid. 
much more complex. It is a socially directed process drawing a portrait of the mad and stimulating public opinion regarding their existence, their alleged size in the society, the danger they represent to the people and the actions which should be taken against them. In the process of drawing an image of the mad, the negation of madness plays an equal role to proving it. To refute an accusation of madness is also to assert the existence of specific standards and criteria of proving it, which does not exist in the object at hand. Such an assertion adds more to the set of criteria and statements of the discourse, which are needed to prove the accusation of madness. Presenting an excuse for madness or for the actions of the mad plays a similar, though slightly different, role. The object of the discourse here is mad but the reason for his/her madness is to be discussed and understood; a process which reveals a specific understanding of madness itself and of "how it works". The analysis of the way the press tries to find an excuse for the mad actions of the mad person helps to identify a social process, which serves to understand and justify the actions taken by a mad person. In the coming part, the article will try to identify such patterns in the discourse.

In reporting the "massacre of the three children in al-Minyâ", A/Jumuhûriyya reporters chose the title "Nehâl, Khulûd and Ziyâd... victims of a mad father and a greedy mother." 42 The killer was named mad on account of the severity of the crime and its devastating nature. This accusation of madness was assured in the next days in this same newspaper and in other newspapers which described the accused as being mad. What is interesting in this part is not the accusation of madness but rather the accusation of "greed", which was thrown at the wife. The accused husband has thrown an accusation against his wife, when he was arrested. He said that she drove him to committing this act by humiliating him and that he slaughtered his children "to be relieved from the torture of my greedy wife." 43 The claims of the accused against his wife were given attention by reporters and newspapers. Rizq and others added to their article in Al-Wafd a small section under the title: "Al-Wafd interviews the grieving mother: My problems with my husband are as normal as those of other couples." ${ }^{44}$ In this section, the wife was required to respond to the accusations of her husband. Mamdûh Hasan took this investigation a step further in his Al-Wafd article: "So that the massacre of al-Minyâ shall not recur: 7 million psychiatric patients threaten to take revenge on their families." 45 The article was mainly centred on the

42. "Nehâl, Khulûd and Ziyâd... victims of a mad father and a greedy mother", AlJumuhûriyya, op. cit.

43. Ahmad Rizq, Imân Ibrâhîm and Mukhtâr Mahrûs, "Arresting the teacher accused of slaughtering his three children", Al-Wafd, April 2, 2004.

44. Ibid.

45. Mamdûh Hasan, op. cit. 
danger of such patients to the society, taking as an example the previous incident. However, the reporter chose a subtitle, "Competition over power within the couple pushes one of them to chronic depression," which reiterates the claims of the accused husband to his wife. In the article, the reporter blamed the working women for marginalizing the role of the man and for "running the house on their own." 46 He added: "The wife became the one who runs the house, from receiving the private tutor to taking the children to the doctor [...]. The man disappeared from these daily tasks and so the ship started having two skippers and, as our traditional proverbs insist, this ship with two skippers is doomed to sink. The conjugal conflict ends by one of them having passing psychological problems, which develop into chronic depression that might lead to explosion at any time driving the patient to commit a massacre inside the family." "'Tthmân 'Allâm, in Al-Maydân, chose to narrate, in his article "The murderer of his three children confesses to Al-Maydân: Hanging is better than the humiliation of women," the story of the accused about how his wife used to tell him that he is not man enough. ${ }^{48}$

In the previous example, the accusations of the "mad" husband were considered serious. Not only did the reporters reiterate the story the accused told about his wife, but also they shared his views and used the opportunity to launch a crusade against working women and the domination of women over the household. The actions of the accused qualified him to the accusation of madness, but, in this case, there was a plausible justification for his madness. His wife persecuted him and drove him to this condition and to this crime.

In this example, the accusation of madness was used to propose masculinist and "conservative" views about the conditions of women, men and married couples. The madman was seen as a victim of the actions of his wife and the conditions of men versus women in the society. The noteworthy finding is that the justification of madness did not release the accused from the imposed alienation as a result of "his madness", but it added a condemnation to certain actions, which were thought to bring this madness about and result in its devastating outcome.

\section{CRIME AND PUNISHMENT: CONFINEMENT AND TRIVIA}

Reporting crimes has always been linked to reporting the juridical process of punishment. The task of the press is to ensure the awareness of the uselessness of crime and the certainty of the subsequent punishment. Due to the enormous

46. Ibid.

47. Ibid.

48. 'Uthmân 'Allâm, "The murderer of his three children confesses to Al-Maydân: Hanging is better than the humiliation of women", Al-Maydân, April 8, 2004. 
delay of Egyptian courts, the actual sentence is less interesting to the reporting press. However, the punishment that concerns us here is not mainly the sentence of the judges, carried out by the concerned authorities, but the judgment thrown by the journalist himself. The criminalization and the severity of the crime are, in fact, defined prior to any actual investigations. The judgment is thus expected by the readers, who will not be interested in following the case till the end.

Especially in the case of the crimes committed by the alleged mad, the punishment is more of the reporter's responsibility. The Egyptian criminal law, following the obsolete distinction, ${ }^{49}$ exempts the mentally ill from punishment, but does not exempt "psychological patients". The differentiation between the two categories depends on the opinion of the court-appointed expert and, eventually, on the judge himself. The reporters, however, do not show any attempt to classify the alleged mad criminals into one of the two categories. They propose their own judgment in a different manner. Accordingly, the reporter does not name a certain punishment. However, through the development of the discourse and the repetition and succession of the statements, the message containing the appropriate punishment is delivered.

'Allâm, for instance, passes a judgment on the teacher, who was accused of murdering his three children, in the title of his article, which reads, "... hanging is better than the humiliation of women,"50 The judgment in this case was given by the tongue of the accused himself. Other similar examples exist, either in such a flagrant manner or in a subtler one, which depends on "common sense", suggesting capital punishment for murder, for instance.

What is more important in this field is how a judgment is passed against the mad people in general, depending on a single case of madness. As seen above, the discourse tends to exaggerate the "danger" of the mad and to create a state of fear towards their presence in the society. They were named "time bombs"

49. The term "neuroses" was described by William Cullen in 1784 as diseases of nerves and muscles. The term "psychosis", however, was described by Feuchtersleben in his Lehrbuch der ärztlichen Seelenkunde, Wien, C. Gerold, 1845. English translation by H. Evans Lloyd, The Principles of Medical Psychology, London: Sydenham Society, 1847. The term psychosis was meant to denote 'a mental disorder which affected the personality as a whole' and was a subcategory of the then much wider category of the neuroses. Therefore, neuroses were seen as diseases with a physical cause. Psychoses, by contrast, were viewed as diseases of the mind and not generally of physical origin. In the beginning of the twentieth century, the situation was reversed and most physicians believed that neuroses were of "psychological" origin while psychoses were of organic causes. With the advances in neurophysiology, the distinction between psychosis and neurosis becomes more obscure, if not obsolete.

50. Ibid. 
and "threats to society as a whole". They were claimed to be present "among us" ready to take revenge on their families, and so on. The answer in most of these cases was the confinement. Reporters repeatedly wondered about the number of beds in psychiatric hospitals and psychiatric wards, demanded their increase and the inclusion of as many "mad" as possible inside such institutions of confinement. Reporters demanded more inspection in such hospitals and requested the creation of a "file" for each and every patient.

The accused "mad" were condemned and all other "mad" people were also condemned in the process. The reporters were very enthusiastic towards demanding strict policing of the "mad", their confinement and supervision, and protecting the society from them as much as possible.

Obviously, confinement is a favourite theme. However, policing and strict supervision, through files and reports, were also important alternatives. There was no difference in this regard between opposition, state-owned and government-leaning papers. They all presented a discourse which aimed at protecting the society from the mad and took part in a crusade against "those people".

From the previous brief discussion, it seems clear that the discourse formulated in the Egyptian press about mad people serves a very important political end. The discourse was very efficient in activating a mechanism of exclusion and alienation to be used against a special group of objects. Such objects included both persons, the mad, and phenomena, the violence in society for example. These objects were included within the realm of the discourse through the use of two essential elements, both depending on a statement of "incomprehension". Psychological or mental illness was viewed as strange and eccentric. In this regard, the testimonies of the proper experts and any relation with such experts were enough proof of madness. In virtually all cases, the testimonies of such experts were full of scientific mistakes and misinterpretations of basic psychiatric and psychological concepts. However, none of that was important. The only relevant fact was their titles. The incomprehensible nature of the act was another factor for formulating an accusation of madness. The acts, which contained "extreme" brutality or violations of social taboos, were "incomprehensible" enough to be mad and thus alien to a puritan society.

The "mad" discourse about the "mad" people proved to be an important and efficient method of alienation and thus protecting the hymen of an allegedly virgin society. The questions the paper was trying to analyse are how this alienation is useful for the integrity of a specific puritan image of the society and how this image of the society protects itself from certain inexplicable acts, which violate the political, religious and moral taboos. 


\section{CITED WORKS}

Bourdieu Pierre, 1991, Language and Symbolic Power, Cambridge, Polity Press.

Evans Lloyd H., 1847, The Principles of Medical Psychology, London, Sydenham Society.

FeuChtersleben Ernst von, 1845, Lehrbuch der ärztlichen Seelenkunde, Wien, C. Gerold.

Foucault Michel, 1969a, L'Archéologie du savoir, Paris, Gallimard.

- 1969b, Histoire de la Folie, Paris, Gallimard.

Lopez ShaunT., 2005, "Madams, Murders and the Media" in Arthur Goldschmidt, Amy J. Johnson and Barak A. Salmoni (eds), Re-invisioning Egypt 19191952, Cairo, American University in Cairo Press, pp. 371- 397.

Prejean Helen, 1994, Dead Man Walking, Vintage, Vintage Editions.

Renneville Marc, 2003, Crime et Folie: Deux siècles d'enquêtes médicales et judiciaires, Paris, Fayard, p. 15.

Walzer Michael, 1994, Thick and Thin: Moral Argument at Home and Abroad, Indiana, University of Notre Dame Press. 